\title{
WANITA DAN KEADILAN: MENAKAR KEADILAN POLIGAMI DALAM NOVEL ATHIRAH
}

\author{
Santi Puspitasari \\ Institut Agama Islam Al Falah As Sunniyyah Kencong Jember \\ santypuspitasari06@gmail.com \\ Qurrotul Ainiyah \\ Institut Agama Islam Al Falah As Sunniyyah Kencong Jember \\ Ainishomad27@gmail.com
}

Abstract: This paper will be explained about how family justice the polygamy based on the gender perspective, which has interpreted through the Athirahh novel. Considering that in this novel tells about the conflict in the polygamous family life carried out by Haji Kalla. Therefore the contributions of this research are: Firstly, the gender justice concept: marriage commitment and relation. The impartiality for a polygamous family is quiet difficult because of the balance of a polygamous family it is not only about the living sharing but also the feeling sharing. There might be a polygamy justice if the couple has a commitment to remain for the couple and maintain the marriage even though there are those who getting hurt because of that polygamy. Secondly, as told in the Athirahh novel, the figure of the woman who was hurt because of the polygamy had been done by her husband, but she was able to manage her mental and keep her good behavior in front of her husband and her children, so that was why the marriage commitment was maintained. But there was an inequality in the relation and the task division because Haji Kalla spent his time with his new wife more than the old one. Athirah had to has burden more because of it. In addition to keep her family, she also had to work for them. 
Keyword: justice, polygamy, the athirah novel.

Abstrak: Paper ini akan memaparkan bagaimana keadilan Keluarga berpoligami perspektif gender, yang teriprentasikan lewat karya novel Athirahh, mengingat dalam novel ini banyak bercerita tentang konflik dalam kehidupan keluarga berpoligami yang dilakukan oleh haji Kalla. Maka kontribusi penelitian ini adalah: Pertama, dalam konsep keadilan gender: komitmen dan relasi perkawinan, keadilan pada keluarga poligami dirasa sulit sekali, karena takaran keadilan berpoligami tidak hanya pada pembagian nafkah dhohir akan tetapi juga nafkah batin. Dan keadilan poligami bisa saja terjadi jika pasangan mempunyai komitmen untuk tetap ada bagi pasangan dan mempertahankan perkawinan walaupun ada pihak tersakiti sebab berpoligami. Kedua, diceritakan dalam novel Athirah, sosok perempuan yang tersakiti secara batin akibat poligami yang dilakukan suami, akan tetapi dia mampu mengelolah kejiwaan dan menjaga prilaku baik dihadapan suami maupun anak- anak. Sehingga komitmen dalam perkawinan tetap terjaga, akan tetapi relasi dan pembagian tugas dalam keluarga mengalami ketimpangan, karena haji Kalla lebih banyak menghabiskan waktu rumah di istri muda dan beban Athirah menjadi double burden, selain mengurus keluarga dia juga bekerja mencari nafkah.

Keyword: keadilan, poligami, novel athirah

\section{PENDAHULUAN}

Keluarga merupakan bentuk hubungan yang diatur oleh agama, diterapkan hukum dan diinternalisasi individu. Qur'ān menekankan pentingnya keluarga inti dan mengecilkan makna penting kelompok-kelompok sosial yang lebih besar seperti suku atau klan (Watt, 1956: 272-289) Qur'ān menggunakan istilah-istilah yang beragam untuk menyebut keluarga; antara lain $\bar{a} /$ (berarti rumah tangga atau pengikut (Lane, 1968: 1,127), ahl, bayt, 'ashīrah, dan qurbā. Istilah-istilah ini bisa berarti sehimpunan orang yang tinggal dalam rumah yang sama atau yang berasal 
dari garis keturunan yang sama (Gil'adi, 2006:2,173). Ketika keluarga menjadi bagian kecil dari kelompok sosial, maka benar adanya jika keharmonisan dan kedekatan anggota keluarga akan berdampak pada ketahanan keluarga untuk melakukan penyimpangan akibat pengaruh dari luar.

Berbincang keluarga, tentu tidak akan terlepas dari keharmonisan dalam keluarga tersebut. Keharmonisan keluarga harus dijaga dengan cara memperkokoh komitmen dan relasi pernikahan. Komitmen dan relasi dalam keluarga harus dibentuk atas kesepakatan bersama, suami istri harus memperlakukan pasangan masing- masing dengan sopan dan santun (Mulia, 2004:20), semakin baik relasi yang dibangun dalam keluarga, maka akan mempermudah untuk menjaga keharmonisan dalam keluarga tersebut. Misalkan: ketika mengambil keputusan tidak hanya disentralkan pada satu orang yaitu bapak. Istri dan anak juga harus dilibatkan dalam bermusyawarah mengambil keputusan penting dalam keluaga.

Keluarga merupakan kumpulan individu-individu yang dibangun akibat dari pernikahan, tapi secara umum George Murdock dalam buku Social Structure membaca keluarga sebagai kelompok sosial dengan karakter tinggal bersama, terdapat kerja sama ekonomi, dan terjadi proses reproduksi (Murdock, 1965:67). Selain karakteristik itu, Murdock mengklasifikasi tipe kekuarga menjadi tiga; keluarga inti (nuclear family), keluarga poligami (polygamous family) dan keluarga batin (extended family). Jika dalam nuclear family dan polygamous family keluarga yang merupakan kelompok social menjalan fungsi keluarga secara seksual, reproduksi, pendidikan dan ekonomi. Maka extended family belum tentu menjalankan semua keempat fungsi tersebut (Murdock, 1965:70).

Mengadopsi tipe keluarga oleh Murdock, kajian keluarga dalam makalah ini terfokus pada tipe polygamous family, dengan merefleksikan sebuah kisah nyata dari novel Athirahh karya Alberthiene Endah berdasarkan kisah kehidupan sosok nomor dua di Indonesia yaitu Wakil Presiden Muhammad Jusuf Kalla (Endah, 2016). Dibalik kebesaran nama Jusuf Kalla ada cerita menarik yang mungkin tidak 
manis, yakni kisah Athirah wanita yang sabar, penuh kasih sayang, keteguhan hati dan terlihat tegar walaupun menyimpan banyak pilu akibat terlalu banyak luka dan kepahitan dari kehidupan rumah tangganya. Tokoh Athirah ini adalah ibu kandung Yusuf Kalla yang biasa dipanggil Emma'.

Keluarga Haji Kalla dan Athirah merupakan keluarga yang harmonis dari saudagar kaya raya yang cukup dikenal oleh masyarakat. Sampai pada ahirnya Kalla yang biasa dipanggil bapak oleh Yusuf memilih menikah lagi dan menduakan cinta Athirah atau emma'. Sebagaimana yang diceritakan Jusuf dalam Novel Athirahh: "Aku mengenal kata poligami, tapi tidak ku bayangkan itu akan menjadi bagian dari sejarah keluargaku" (Endah, 2016:22). Akan tetapi sosok ibu yang luar biasa tetap tergambarkan meski dalam kondisi psikis yang begitu tertekan karena menjadi isteri yang di poligami oleh suami, "Emma tetap ada untuk Bapak dengan senyum dan pelayanan yang tak pernah berkurang takarannya. Disajikannya sarapan dan makan malam tiap kali Bapak datang. Dibereskan pula meja itu dengan wajah sunyi yang sama tiap kali Bapak pergi" (Endah, 2016:117).

Gambaran novel Athirah pada paragraf diatas, hakikatnya menyajikan cerita kepedihan akibat dipoligami dari sosok wanita yang bernama Athirah. Bukannya terpuruk, kepedihan itu justru menjadi cambuk bagi Athirah untuk bangkit menjadi wanita yang sukses dalam mengurus rumah tangga, membesarkan dan mendidik anak-anaknya menjadi orang besar, dan bahkan menjadi pembisnis kain tenun yang sukses. Ulasan novel Athirah ini memang condong pada issu ketidakadilan pada perempuan dan anak dalam kehidupan berpoligami. Karena seharusnya kaum perempuan memiliki hak-hak kemanusiaan yang sama dengan hak-hak yang dimiliki kaum laki-laki. Maka hubungan antara suami dan isteri adalah hubungan horizontal bukan hubungan vertikal, sehingga tidak terdapat kondisi yang mendominasi dan didominasi.

Pada kenyataannya, keadaan keluarga dalam tradisi keluarga Islam menempatkan istri sebagai second human, cerita dalam novel Athirah adalah sebuah gambaran bahwa laki- laki itu pemangku keluarga, laki-laki terutama sosok 
bapak adalah penguasa dalam keluarga. Seorang istri harus tunduk dan manut pada suami, bahkan ketika suami menyakitinya dengan pembenaran atas nama agama (poligami) sang istri tidak bisa berbuat apa- apa dan hanya bisa menyalahkan diri sendiri atas apa yang telah diperbuat suami. Yang demikian tidak lepas dari pandangan keagamaan masyarakat muslim yang terkonstruk oleh tradisi patriarkhi yang teruraikan dalam beberapa kitab klasik, terdapat beberapa lembar dalam kitab klasik memiliki beberapa nilai inferioritas perempuan dibanding laki-laki (Ainiyah, 2017:53-71).

Terjadinya pengingkaran dan diskriminasi terhadap perempuan seperti cerita di atas, menurut Masdar sebagai pangkal mula adanya pelebelan sifat- sifat tertentu pada kaum perempuan; bahwa kaum perempuan lemah, lebih mendahulukan emosional dari pada nalar, cengeng dan hanya sebagai pengurus rumah tangga. Sehingga perempuan hanya berlebel sebagai second human yang harus tunduk kepada laki- laki (subordinat laki- laki), manusia marginal, sifat yang lemah sering menjadi sasaran tindak kekerasan laki-laki dan perempuan menerima kerja lebih berat dari yang dipikul laki- laki (Mashudi, 1997:55-57). Seorang istri terutama dalam tradisi di Indonesian, harus mengerjakan urusan domestik rumah tangga sekaligus mengasuh anak- anak mereka, bahkan tidak sedikit yang harus bekerja untuk memenuhi kebutuhan keluarga.

Kajian ini akan mengeksplor tentang keadilan poligami dalam kerangka teori komitmen dan relasi dalam keluarga yang tereprentasikan lewat karya novel Athirahh, upaya yang dibangun oleh Kalla dan Athirah untuk menjaga keutuhan rumah tangga tidaklah mudah, setidaknya pilihan Kalla untuk berpoligami mengharuskan dia untuk berbuat adil kepada kedua istri dan juga anak-anak mereka. Maka dari itu tulisan ini akan menfokuskan pembahasannya pada; Pertama, Konsep Keadilan Gender: Komitmen dan Relasi dalam Keluarga. Kedua, sinopsis kehidupan keluarga Athirah. Ketiga, menakar keadilan keharmonisan keluarga poligami dalam novel Athirah. 


\section{KEADILAN GENDER: TENTANG KOMITMEN DAN RELASI DALAM KELUARGA}

Secara ideal, Islam telah membuka peran dan kesempatan yang sama antara lakilaki dan perempuan untuk berprestasi dalam berbagai sektor kehidupan. Karena al-Qur'ān menjelaskan bahwa yang disebut manusia ideal itu adalah manusia yang bertaqwa, pernyataan ini berlaku untuk semua jenis kelamin. Akan tetapi wacana berikutnya, pembahasan perempuan dalam pemahaman patriarki yang mengatas namakan agama terasa tidak enak didengar dan memang terasa sulit dibantahkan. Lebih sekedar berada dibawah superioriritas dan dominasi laki-laki, adanya keyakinan dari kaum patriarki bahwa hawa secara harfiyah diciptakan dari tulang rusuk adam, menunjukkan bahwa diciptakan sebagai pelengkap bagi laki-laki (Mashudi, 2000:169). Yang demikian memang tak menyenangkan bagi mereka yang meyakini bahwa perempuan sama mulia martabatnya dengan laki-laki, karena dalam pemahaman mereka semangat Islam yang sesungguhnya justru egaliter.

Islam adalah ajaran yang sangat memperhatikan masalah kesetaraan peran dan relasi gender, perbedaan laki-laki dan perempuan secara syariyah tidak cukup hanya dikaji secara biologis, tetapi memerlukan pengkajian secara non biologis. Perspektif gender dalam al-Qur'ân mengacu pada semangat dan sifat-sifat universal, adanya kecenderungan permohonan bahwa konsep-konsep Islam banyak memihak pada gender laki-laki belum tentu mewakili substansi ajaran alQur'ân. Prinsip kesetaraan gender dalam al-Qur'ân antara lain mempersamakan kedudukan laki-laki dan perempuan sebagai hamba Allah yang menjadi implikasi secara sosioteologis (Muzani, 2014:47).

Sama halnya yang terjadi pada keluarga Islam, begitu didominan oleh penafsiran ajaran agama yang tereduksi dengan budaya patriarki, sehingga seorang kepala keluarga (suami) memiliki hak tunggal atas perempuan sekaligus kontrol monopoli atas seksual dan reproduksi mereka (Memissi, 1999:104). Dari sinilah memicu ketimpangan gender yang memicu subordinasi yang menganggap perempuan inrasional dan emosional, marginalisasi, stereotip negative, double 
burden dan kekerasan terhadap perempuan. Ketimpangan dalam keluarga adalah factor yang menyebabkan hilangnya keadilan gender seharusnya menjadi hak seorang istri, akibatnya banyak istri hanya bisa pasrah dan menerima semua perlakuan suami terhadap dirinya berlandaskan kepatuhan. Sehinggga muncul stateman bahwa perempuan hanyalah konco wengkeng bagi kaum laki-laki.

Pernikahan dengan framing kebahagiaan tidak bisa serta merta berlandaskan pada satu misi yang dibangun oleh kedua mempelai. Tetapi, yang membuat pernikahan itu menjadi bahagia karena adanya komitmen pernikahan yang kuat. Semakin kuat komitmen yang dibangun maka semakin besar peluang untuk bisa mempertahankan pernikahannya. Komitmen pernikahan menjadi penentu terhadap berlangsungnya dan keutuhannya sebuah rumah tangga. Oleh karenanya, komitmen pernikahan bukanlah semata-mata tujuan dari pernikahan itu sendiri, melainkan adalah sebuah roda pikir yang terus dibangun dan diperkuat dalam rangka eksistensi pernikahan dalam bingkai kebahagiaan.

Komitmen dalam pernikahan dan keluarga dapat diartikan sebagai kekuatan yang menjaga individu tetap bersama dalam ikatan tersebut. Kekuatan tersebut dapat berupa cinta dan kasih sayang, maupun perasaan takut akan kesepian bila mereka mengakhiri hubungan tersebut (Taylor, 1997:122). Johnson kemudian membagi pengertian komitmen dalam perkawinan terkait tiga faktor utama yang memengaruhinya, yaitu;

1. Faktor komitmen personal, yaitu faktor sikap individu yang ingin melanjutkan hubungan karena mereka tertarik kepada pasangannya, hubungannya atau status berpasangan (couple identity).

2. Faktor komitmen moral, yaitu faktor nilai-nilai moralitas dalam hubungan perkawinan seperti bahwa pernikahan adalah hubungan yang kuat, serius, dan abadi.

3. Faktor komitmen struktural, yaitu faktor yang dipengaruhi oleh alasanalasan struktural, seperti tuntutan/tekanan sosial dan investasi individu dalam hubungan perkawinan yang memberikan kontribusi untuk rasa 
terikat dalam hubungan, dan apakah seseorang ingin berpisah atau tidak. Komitmen ini berhubungan dengan kebahagiaan dalam perkawinan (Johnson, 199:160-177).

Dalam hubungan perkawinan, komitmen perkawinan memang berkaitan dengan kebahagiaan perkawinan yang dirasakannya oleh individu, meskipun tidak selalu simultan. Artinya, terdapat beberapa pasangan yang tidak bahagia namun mampu tetap berkomitmen meningkatkan kualitas hubungannya, begitu pula dengan pasangan lain yang mengakhiri hubungannya. Sebagian pasangan ada yang mampu mempertahankan hubungan pernikahan seumur hidup walaupun hubungan itu tidak memuaskan dan membahagiakan (Previti \& Amato, 2003:561573).

Komitmen perspektif hukum keluarga Islam telah banyak disarikan oleh para ulama/pakar dengan perbagai prinsip dan penjelasannya. Yang terangkum dalam sembilan prinsip (Mudzakir, 1987:20-22). yakni : Pertama, prinsip mitsaqan ghalidzan (perjanjian/komitmen yang teguh/suci). Kedua, prinsip mawaddah wa rahmah, yang terbentuk dari suasana hati yang penuh keikhlasan dan kerelaan berkorban demi kebahagiaan bersama. Ketiga, prinsip mu'asyarah bi al-maruf (interaksi yang santun dan beradab) baik dalam sikap, ucapan, maupun perbuatan. Keempat, prinsip musawah (kesetaraan), yakni suami isteri berkomitmen berada pada posisi yang setara dan sederajat. Kelima, prinsip musyawarah (komunikasi yang intensif dan berkualitas). Atas dasar prinsip musyawarah ini, suami atau isteri tidak mengambil keputusan pentingkhususnya menyangkut kehidupan keluarga-, secara sepihak melainkan senantiasa perlu dirundingkan atau dimusyawarahkan bersama. Keenam, menjadikan pernikahan sebagai jalan untuk mendapatkan ridho Allah. Ketujuh, mendidik keturunan dengan cara-cara islami. Kedelapan, harta yang dimakan haruslah dari rezeki yang halal. Kesembilan, menjalani hak dan kewajiban dalam berkeluarga sesuai ketentuan syariat. 
Komitmen yang menyertai perjalanan pernikahan dan keluarga selalu dinamis dan dialektis, sehingga kualitasnya dapat dilihat sejauh mana ia mampu mengatasi dinamika dan dialektika kehidupan yang dilalui. Suami isteri telah berjanji atau berkomitmen atas nama Allah akan menjaga amanah itu. karena amanat pernikahan adalah sesuatu yang diserahkan kepada pihak lain disertai dengan rasa aman dari pemberinya karena yakin bahwa apa yang diamanatkannya itu akan dipelihara dengan baik (Lestari, 2012:47). Dalam keluarga yang berpoligami menjaga komitmen dalam rumah tangga membutuhkan komitmen yang lebih lagi, karena disadari atau tidak bahwa ketika suami berpoligami dia telah menghianati dan menyakiti istri bahkah bisa jadi menyakiti anak-anaknya juga.

Selain komitmen pernikahan hal terpenting untuk menjaga keutuhan rumah tangga adalah relasi. Dengan relasi yang baik, maka akan terpenuhi konsep yang tersurat dalam an-Nisa' (03): 19 wa 'āshirūhnunna bi al-ma'rūf yang dimaknai imam Nawawi sebagai kewajiban laki- laki mempergauli istri dengan baik, adil dirumah (bagi yang berpoligami), memberi nafkah dan santun dalam berbicara. Dan istri mempunyai hak seimbang dengan penilaian yang baik menurut syara' yaitu memiliki hak untuk diperlakukan dengan baik dan terbebas dari saling menyakiti (Ainiyah, 2018: 211-226).

Relasi pada awalnya dibangun dari perkawinan antara laki-laki dan perempuan tahapan ini disebut dengan relasi pasangan suami istri, kemudian lahir anak pertama yang memunculkan relasi baru yakni orang tua-anak. Selanjutnnya keberadaan anak-anak berikutnya merupakan bentuk relasi sibling (saudara kandung) (Lestari, 2012:9). Ketiga bentuk relasi tersebut merupakan relasi dari tipe relasi keluarga inti (nuclear family). Jika relasi itu semakin meluas kepada kakek-nenek, paman-bibi, cucu, keponakan dan saudara ipar, maka itu bentuk dari tipe keluarga batin (extended family) (Lestari, 2012:9). Karena dalam relasi keluarga memiliki karakteristik yang beda, maka pemaparan teori relasi ini penulis 
fokuskan relasi pada keluarga inti (nuclear family) dan keluarga poligami (polygamous family).

Aturan relasi dan keseimbangan antara suami -istri ditegaskan Islam dalam QS. An- Nisa': 19 tentang pergaulan suami istri yaitu muasyarah bil ma'ruf. Dalam ayat tersebut menjelaskan betapa pentingnya relasi suami istri yang didasari dengan keseimbangan antara hak dan kewajiban sehingga tercipta suasana hati yang damai dan harmonis, sakinah, mawaddah wa rahmah. Untuk menafsirkan makna muasyarah bi al- ma'rūf maka mufidah menjelaskan harus adanya relasi dan keseimbangan antara suami istri yang teruraikan sebagai berikut (Ch., 2008:180).

a. Menerima kondisi pasangan apa adanya: Kesadaran untuk memahami kekurangan dan kelebihan pasangan dengan hati yang tulus akan menjadi modal utama dalam melanggengkan pernikahan. Seringkali pernikahan bubar karena masing-masing pasangan selalu melihat kekurangan bukan kelebihan sehingga selalu melihatnya dengan kacamata kebencian bukan kasih sayang.

b. Saling memahami dan menjalankan hak dan kewajiban, jika masingmasing suami istri melaksanakan hak dan kewajibannya dengan baik, maka di dalam berumah tangga tidak ada relasi kuasa.

c. Mengembangkan sikap amanah dan mengedepankan kejujuran dengan cara menjaga amanah dan sikap keterbukaan. Karena seringkali pernikahan putus di tengah jalan karena tidak ada kejujuran dan tidak menjaga amanah dengan baik. Kecurigaan terhadap pasangan akan menimbulkan suasana yang tidak harmonis.

d. Saling memahami perbedaan pendapat dan pilihan peran: perbedaan kepribadian, keinginan, kebutuhan, dan selera. Akan menimbulkan konflik konflik kecil, maka dari itui baik suami maupun istri harus bisa memahami perbedaan karakter masing-masing pasangan dan sensitif 
terhadap perbedaan tersebut. Sedangkan pilihan peran dalam rumah tangga tidak akan menjadi masalah jika kedua wilayah tersebut mendapatkan penghargaan yang setara. Landasan pada moralistik dan akhlaq karimah relasi suami istri harus didasarkan pada prinsip mu'syarah bi al-ma'rūf sehingga mengedepankan nilai-nilai kemaslahatan, demokratis, manusiawi sehingga peran tersebut bisa dikompromikan (Lestari, 2012:148).

e. Mengatasi masalah dalam keluarga harus berdasarkan dihadapi, diskusi, musyawarah dan mencari alternatif solusi terbaik antara suami dan istri. Proses pengambilan keputusan harus pada posisi setara keduanya merasa saling membutuhkan, melengkapi dan tidak sepihak. Setiap masalah yang muncul dalam keluarga dapat ditelusuri faktor penyebabnya, Identifikasi masalah dan mencari faktor penyebab sangat penting untuk mencari solusi permasalahan yang terjadi.

f. Menghindari kekerasan dalam rumah tangga; keluarga sakinah tidak dapat dibangun ketika hak-hak dasar pasangan suami istri dalam posisi tidak setara. Hubungan hierarkis biasanya menimbulkan relasi kuasa yang berpeluang pada subordinasi. Ada yang berkuasa dan ada yang dikuasai.Budaya patriarkhi akan memposisikan perempuan sebagai korban subordinasi. Kenyataan di lapangan menunjukkan bahwa istri sering menjadi korban kekerasan dalam rumah tangga. Oleh karena itu perlu adanya unsur yang saling melengkapi dalam keluarga, dalam melakukan peran-peran yang seimbang sehingga keduanya merasa saling membutuhkan.

\section{SINOPSIS KISAH KEHIDUPAN KELUARGA ATHIRAH}

Novel Athirahh merupakan otobiografi wakil presiden Jusuf Kalla. Yang menarik dari novel ini adalah tokoh utama dalam kisah ini yakni sosok Athirah sebagai ibu ideal dimata Yusuf dan sekaligus pengusaha kain sutra yang sukses. Bagi Yusuf 
emma panggilan dari Athirah adalah ibu yang luar biasa, perempuan yang penyabar, tegar dan penuh kasih sayang dalam mengurus rumah tangganya. Dia bisa menjadi ibu sekaligus menjadi sebagai bapak untuk anak- anak mereka, tak kala sang ayah memilih untuk berpoligami yang secara otomatis akan berbagi dari perhatian, materi dan kasih sayang dengan keluarga yang lain.

Berawal dari kepindahan keluarga Kalla dan Athirah dari Bone ke kota Makassar untuk mencari kehidupan ekonomi yang lebih baik. Mereka berdua memulai membuka usaha kelontong yang ahirnya menjadi maju dan banyak pelanggan yang datang. Merasa sukses dengan usahanya, Athirah memutuskan untuk memboyong keenam anaknya ke Makassar dan serta membawa Aisyah salah satu saudara jauh untuk menjadi asisten rumah tangga. Di Makassar keluarga ini hidup bahagia, walaupun banyak sekali jumlah anggota keluarga, mereka bisa saling bahu membahu mengurus pekerjaan rumah. Yusuf sebagai anak laki-laki tertua menjadi harapan sang emma' untuk bisa menjaga saudarasaudara yang lain. Sang emma' berharap pada kelak dewasa nanti Yusuf bisa menjadi seperti sang bapak (panggilan Kalla ayah Yusuf) yang sukses dalam memimpin keluarga dan sukses dalam berbisnis.

Kebiasaan yang paling hangat dalam keluarga besar Athirah adalah saat makan malam dan sholat shubuh berjama'ah bersama para karyawan. Makan malam merupakan hal terpenting untuk mempererat kedekatan antara satu dengan yang lain. Pada momen makan malam itulah sang bapak menunjukkan perhatian kesemua anggota keluarga, dia selalu menanyakan rutinitas istri dan anak- anaknya setelah seharian disibukakan dengan pekerjaannya sebagai pengusaha. Bapak juga menanamkan kedisiplinan dalam menjalankan keagamaan kepada anak- anaknya, menumbuhkan etos kerja yang tinggi dan mengajarkan kesederhanaan walaupun mereka berbasik keluarga yang kaya raya.

Hingga tahun 1955, sebuah prahara menimpa keluarga mereka. Disaat Athirah mengandung anak yang kedelapan Athirah mulai mencurigai perubahan sikap sang abbah. Abbah mulai suka bersolek dan suka meninggalkan rutinitas 
makan malam yang menjadi moment terpenting dalam keluarga. Berita tentang bapak sedang jatuh cinta lagi dengan perempuan lain begitu banyak terdengar di masyarakat, mendengar kabar yang tidak menyenangkan Athirah mencoba bersikap tegar, dia hanya diam dan menjalankan seluruh aktivitasnya tanpa ada perubahan yang mendasar. Hanya mata dan batinnya yang berbicara banyak, sebagai istri dia sudah lama ia merasakan ada yang berubah pada suaminya, tapi semuanya dihadapi dengan sabar.

Ahir batas rasa penasaran Athirah sudah sampai pada puncak, dia mengutus Ucup (panggilan Yusuf) untuk menyelidiki kebenaran tentang kabar abbah menikah lagi yang beredar dimasyarakat. Akan tetapi penyelidikan Ucup tidak membuahkan hasil, sehingga dengan berat hati emma' memanggil Rusdi orang kepercayaan abbah untuk mengkonfirmasi kebenaran berita itu. Alangkah sedihnya Athirah mendengar kabar Rusdi bahwa sang suami menikah lagi berbarengan dengan kehamilannya yang terus membesar.

Setelah diketahui menikah lagi, ayah Jusuf membuat keputusan bahwa ia akan lebih banyak menginap di rumah isteri mudanya, namun ia berjanji akan berada di rumah Athirah saat shalat Subuh dan saat shalat Maghrib sampai waktu makan malam (Endah, 2017:27). Kegalauan dan kegundahan hati Athirah tergambar di novel yang ditulis oleh Alberthiene Endah, Athirah merasa tertekan secara psikologis. Tapi dia tidak bisa berbuat apa-apa kondisinya yang sedang hamil tua dan adanya anak-anak lain yang menyebabkan dia bertahan dalam situasi yang menyakitkan ini.

Pada hari-hari disekitar pernikahan bapak, emma terlihat seperti berjuang keras memimpin dirinya memasuki babak baru kehidupan. Sering ia berdiri di muka jendela, seperti hendak melarikan kegelisahan. Pandangannya kosong dan keruh. Seperti hendak berlari, tapi dikepung dinding yang tinggi. Kehamilan emma kian membesar, ia meniti masa hamilnya dengan penderitaan yang bisa ku tangkap dengan jelas. Dari bibirnya tak ada kata-kata yang memberitahukan kepedihan. Tak ada 
tangis. Tapi aku tahu sekujur tubuh emma dibalut duka (Endah, 2017:2728). Jeritan hati Yusuf ketika menceritakan kondisi ibunya.

Emma akan pergi ke orang pintar, itu menyakitkan hatiku. Ku dengar itu dari saudara-saudara permpuanku, Itulah perlawanan emma'. Bukan, ia tidak sedang ingin berbuat jahat. la hanya ingin mendapat kejelasan mengapa bapak berbuat itu. Ini perjalanan yang memijak fase yang sulit. Meski masih remaja belia, aku tahu emma' butuh berproses untuk membangun ikhlas sekukuh-kukuhnya. Dan saat berjalan menuju kukuh, ia terguncang terlebih dahulu (Endah, 2017:100).

Curahan hati yusuf dalam novel Athirah menunjukkan betapa kacau balau hati Athirah ketika mengetahui bahwa sang suami menikah lagi. Namun dia mencoba untuk tegar demi anak-anak, demi kesehatan bayi dalam kandungannya. Athirah mencoba bersabar walaupun gejolak yang tejadi dalam rumah tangga membuat dirinya sempat kehilangan kepercayaan diri. Hingga ia mencari jawaban lain untuk menenangkan perasaan dengan mendatangi orang pintar. Sebagai seorang wanita, Athirah berusaha mempertahankan rumah tangga dan mencari tahu apa yang menyebabkan suaminya menikah lagi walau mengaku masih mencintainya dengan sepenuh hati.

Hingga pada suatu saat Athirah mendapatkan lagi kepercayaan diri, bukan dari sang orang pintar tapi support dari orang -orang yang dia cintai yakni nasehat sang ibu dan komitmen Ucup yang akan menjaga Athirah dan adik-adiknya. Nasehat menarik yang diungkapkan ibu Athirah kepada Athirah; "kain lipan ini seperti pusaka, simpan terus apa yang terpenting untuk hidup mu". Maksudnya keluarga harus dijaga dan dirawat karena keluarga adalah harta paling berharga dalam hidup ini. Hanya bersama Jusuf, Athirah menentramkan keadaan rumah bahwa semua baik-baik saja ada bapak atau tak ada bapak. Athirah sanggat tangguh, keadaan mengharuskan beliau meredam emosi hati melanjutkan hidup dengan separuh hati yang hilang. Sebagai isteri pertama ibu Jusuf sangat menghargai keputusan suaminya meskipun dia memiliki hak untuk menyuarakan 
pendapat. Karena dia sangat menghormati suami meskipun telah dijadikan isteri yang di poligami.

Jusuf remaja tumbuh di tengah gejolak rumah tangga orang tuanya, dia memahami kesedihan yang dialami emma', akan tetapi tak sekalipun dia meminta emma' mempertanyakan alasan berpoligami pada bapak atau bertanya pada emma kenapa "tak melawan" semua hanya dipendam dalam hati. Jusuf remaja sebagai anak laki-laki tertua lebih memilih tampil menjadi pemimpin keluarga dengan delapan adik: Ahmad, Zohra, Saman, Suhaeli, Siti Ramlah, Halimah, Farida dan kakaknya Nur. Menyibukkan diri dengan rajin belajar, dan belajar berdagang kepada kedua orang tua. Nalurinya tumbuh begitu saja karna menyayangi emma'.

Kuat keinginan melindungi emma' dan saudara yang lain, membulatkan hati jusuf untuk tidak meninggalkan Makassar, sementara sikap bapak tak pernah berubah. Bapak sibuk dengan berdagang dan membagi waktu dengan keluarga yang lain. Dia ada saat magrib sampai makan malam serta menjelang shubuh. Namun demikian bapak tetap berwibawa bagi keluarga dan masyarakat. Karena selain bapak masih bertanggung jawab terhadap pendidikan, kesehatan dan kebutuhan-kebutuhan keluarganya. Bapak juga masih terus menanamkan nilai agama, etika dan tanggung jawab dalam bekerja kepada keluarga.

Tumbuh di tengah poligami yang di lakukan bapaknya sangat mempengaruhi kepada kehidupan social Yusuf. Yusuf pernah ingin melamar gadis yang ingin di nikahi tapi dia ditolak orang tua gadis tersebut dengan alasan memiliki riwayat keluarga yang berpoligami. Keluarga Yusuf berasal dari saudagar yang terpandang jadi semua orang tahu tentang kehidupan keluarga Yusuf. Ini yang diceritakan dengan apik oleh Jusuf dalam novel karya Endah ini;

"Mufidah aku suka kepadamu. Aku mencintaimu...." Mufidah itu perasaaku. Dan, aku ingin kau bisa menerimaku. Menerima cintaku..." Kami berdiam diri cukup lama. Mufidah diam diboncengan. Aku membisu. Sebuah pengakuan yang justru berakhir dengan kebingungan. "Jusuf." la menatapku. "Ayahku mrngetahui keluargamu. Orang tuaku tahu ayahmu 
menikah lagi. la selalu mengingatkan aku tentang itu. Kurasa, ia takut aku mengalami hal yang sama dengan ibumu..... Maafkan aku..." Suara Mufidah berhenti bersamaan dengan geraknya yang sangat cepat. la berlari menuju pintu. Cepat sekali. Lalu, menghilang. Aku mematung tak mempercayai kalimat Mufidah. Aku bahkan tak berpikir sampai ke sana. Tapi itulah jawaban Mufidah. Jawaban yang telah menjelaskan segalanya. Jawaban yang tak bisa kubantah. Aku masih mematung beberapa lama. Sesuatu yang perih menggigiti perasaanku. Nyeri sekali. Apa yang kau ciptakan untuk kami, abbah. Kau ada ketika kau mau. Dan, kau pergi ketika kami masih ingin bersamamu. Sekarang, gadis yang ku cintai bahkan menolakku karena kisah yang kau buat (Endah, 2017:300-302).

Perempuan yang terluka lebih berbahaya dari pada singa. Begitu juga dengan Athirahh, usianya masih tergolong muda saat mengalami penderitaan dimadu. Guna mengalihkan pikiran dari suami, Athirah memutuskan untuk menyibukkan diri dengan berbisnis kain sutra. Sehingga bisnisnya menjadi cukup maju dan butuh penanganan serius. Tapi itu tidak cukup, untuk membuat Athirah mengisi waktu luang dengan hal-hal kreatif. Athirah sudah berdamai dengan keadaan, keadaan yang tidak bisa diubah. Athirah memilih menerima dan bangkit mengisi hidupnya atau terpuruk dan kalah. Athirah mengalihkan energi dari luka hati menjadi sesuatu yang berguna, membangun usahanya sendiri. Bahkan disaatsaat suaminya mengalami inflasi dalam bisnis, sosok Athirahh mampu menopang dengan menyerahkan simpanan perhiasan untuk menutupi kebangkrutan yang dialami oleh sang suami.

Athirah perempuan sederhana, pekerja keras, tabah dan tegar dalam menghadapi semua persoalan hidupnya. Memilih menyelesaikan konflik dalam keluarga dengan caranya sendiri. Rasa sakit karena dipoligami oleh suami tidaklah mempengaruhi hormat dia kepada suami dan kasih sayang kepada anak-anaknya. Rutinitas sebagai seorang ibu dan istri Athirah lakukan dengan penuh keikhlasan. Athirah lebih memilih berdamai dengan keadaan, ketidak setiaan sang suami tidak menjadikannya hancur bahkan dia makin menjadi wanita yang kuat. 


\section{MENAKAR KEADILAN POLIGAMI DALAM NOVEL ATHIRAH}

Novel Athirah lahir dari kesadaran reflektif Jusuf Kalla terhadap dampak pekawinan poligami yang dia gambarkan dalam keluarga. Dampak dari perkawinan poligami yang terjadi dalam kondisi sosio-kultural yang tidak ramah dan cenderung mensubordinasi perempuan dengan menggunakan alasan agama, sistem sosial, dan ekonomi. Jusuf bercerita banyak bagaimana poligami berdampak pada psikologis sang ibu dan juga pada keluarga lainnya. Melalui tokoh Athirahh, Yusuf menguraikan berbagai persoalan yang terjadi dalam keluarga poligami, Athirah diceritakan Yusuf sebagai sosok wanita yang sabar, ulet dalam bekerja,telaten dan penuh kasih sayang akan tetapi menyimpan beribu luka dan penderitaan akibat di khianati cintanya oleh sang suami.

"Aku mengenal kata poligami tapi tidak ku bayangkan kata itu akan menjadi bagian dari sejarah keluargaku. Aku menghormati ayahku, Haji Kalla yang terpandang di seantero Makasar. Tapi lalu Bapak mencintai perempuan lain. Dan orang-orang bergunjing tentang itu. Ini pukulan...."(Endah, 2017:22-23).

Kalimat sederhana yang dituturkan Yusuf diatas, menunjukkan ada tekanan kepada sang anak, yang timbul karena sang anak melihat penderitaan ibu maupun karena tekanan sosial dari dilingkungan masyarakat. Ini dapat diidentifikasi dengan teori Chen tentang relasi orangtua- anak dalam memberikan rasa aman (security) (Chen, 2009:335-340), berkurangnya kepekaan bapak Yusuf terhadap anggota anak dan istri, akibat bapak kawin lagi, bisa saja berdampak buruk pada anak. Kebencian muncul karena bapak sebagai sumber masalah dalam keluarga, bahkan akan memberikan traumatik ketika anak- anak mulai remaja. Misalkan trauma untuk berdekatan dengan lain jenis, masyarakat yang masih belum bisa menerima perkawinan poligami akan menyebabkan istri dan anak-anak menjadi kurang percaya diri.

Bias pada perempuan yang mencitrakan perempuan sebagai mahluk yang tidak sempurna (the second class), mahluk yang tidak penting (subordinate), 
dipinggirkan (marginalization), dieksploitasi, dan hanya pengurus domestic rumah tangga (domestication) (Nurhayati, 2012:xxvi). Menyebabkan kerentanan bagi perempuan mendapat kekerasan secara psikis maupun fisik. Anehnya pencitraan terhadap perempuan tersebut dianggap suatu hal yang lumrah dan lazim, sehingga perempuan tidak memiliki pilihan selain diam dan hanya bisa menyalahkan diri sendiri ketika terjadi kekerasan psikis pada dirinya. Itupun tergambar dalam kehidupan Athirah, ketika sama-sama tidak memiliki kekayaan, Athirah berjuang bersama Kalla membangun usaha. Setelah usahanya mulai sukses Kalla mengalihkan peran Athirah sebagai peran domestic, pada ahirnya Kalla berpoligami karena sudah merasa mampu secara finansial untuk menghidupi lebih dari satu istri. Kalla lupa bahwa kesuksesan dia dalam berbisnis juga tidak lepas dari campur tangan Athirah.

Sikap ego haji Kalla menjadikan pembenaran bagi dia untuk melakukan poligami, tega menyakiti hati istri yang telah berkorban banyak pada kehidupan dia dan anak- anak. Menurut penulis pembenaran yang dilakukan oleh Kalla, ketika dia telah memiliki kelebihan dalam finansial, dan melakukan poligami tanpa mempertimbangkan perasaan istri dan anak- anak. Maka hal tersebut dianggap telah mencederai tujuan perkawinan yakni mitsaqan ghalidzan, sejatinya ketika sudah berkomitmen dalam perjanjian suci maka antara suami istri saling mendukung dari segala aspek. Dari komitmen itulah maka akan terjadi pola hubungan yang baik antara suami, istri dan anggota keluarga yang lain.

Pola hubungan yang baik tentu akan menimbulkan keadilan dalam hubungan suami- istri, sehingga hubungan dalam keluarga dapat dibicarakan dan diputuskan dengan baik. Dominan ikhlas dan saling mengerti akan meleburkan keegoan dan kepentingan antara suami- istri, mengutip pendapat Qurrotul Ainiyah bahwa maqām tertinggi dalam hubungan suami- istri adalah maqām berkeadilan yang dilandasi cinta kasih. Jadi dalam keluarga, tidak ada yang merasa unggul dan sak karepe dewe (semaunya sendiri). Kedua belah pihak bermitra dan 
bisa saling mendukung dalam segala hal, maka dominasi kepentingan oleh salah satu pihak tidak akan terjadi (Ainiyah, 2018:53-71).

Menekankan aspek keadilan dalam keluarga poligami, penulis menilai kebanyakan laki- laki pelaku poligami tidak mendiskusikan pembagian materi dan waktu bagi anak dan istri-istri. Lebih jauh lagi, mereka menyebutkan satu-satunya ukuran keadilan di antara para istri adalah materi, padahal Islam telah mengatur dalam surat an-nisa' tentang makna keadilan, yaitu adil dalam mengelola harta, adil terhadap anak, dan adil terhadap para istri. Tentu ihwal saling melengkapi antara suami-istri yang diharapkan al-Qur'ân sulit terjadi, hal demikian karena sangat sulit dalam membagi cinta terhadap beberapa keluarga.

Ketakutan dan kekhawatiran perempuan yang dipoligami secara tidak langsung akan menyebabkan perempuan terlarut dalam kontruksi yang ditanamkan patriarki, masyarakat dan budaya sehingga tidak menyadari kooptasi gender yang menimpa diri mereka dan beranggapan bahwa perbuatan selingkuh yang dilakukan sang suami disebabkan kekurangan dan kesalahan dari pelayanan perempuan kepada suami. Sehingga kebanyakan perempuan yang dipoligami menyalahkan diri mereka sendiri dan merasa tidak percaya diri ketika bergaul dalam masyarakat. Piere Boudieau menyebutkan ini sebagai salah satu bentuk kekerasan simbolik (symbolic violence) yang mana kondisi perempuan tidak menyadari bentuk opresi yang menimpa mereka justru mereka menikmati sebagai sesuatu yang bukan permasalahan (Boudie, 1998:102).

Bentuk symbolic violence terjadi dalam novel Athirah diceritakan dengan bahasa memilukan, sosok Athirah harus berjuang untuk kebahagiaan diri sendiri dan anak-anaknya dengan melawan kesedihan akibat dipoligami;

"Bagaimana emma menyikapi ini? la bangkit belajar. Meski tangan dan pikirannya susah repot mengurus Nur, Aku, Zohra dan Saman, tapi emma membangun diri untuk bisa sepadan dengan kemajuan Bapak. Sejak menikah ia memang telah membantu Bapak di kios pasar baju, di toko yang lebih besar ini emma' membesarkan kapasitasnya. Dibuka studio jahit dan 
ia berkreasi menjual benang jahit beraneka warna hasil celupannya sendiri. Selama itulah emma menjaga hari-hari kami tetap berjalan harmonis dan tertata. Begitulah emma' ia selalu bisa menerbangkan diri mengikuti perjalanan Bapak. Tanpa harus merusak pengabdiannya di rumah, emma' adalah energi yang tak pernah mati untuk bisa bersisian harmoni dengan bapak. la perempuan mengagumkan" (Endah, 2017:114-116).

Akibat dari symbolic violence yang akan memunculkan konflik dalam keluarga, jika tidak ada resolusi konflik berkaitan dengan sikap, perasaan, dan keyakinan individu terhadap keberadaan dan penyelesaian konflik dalam relasi berpasangan. Maka yang terjadi keutuhan dalam rumah tangga bisa hancur; bisa saja akan terjadi broken home ataupun bahkan perceraian. Dalam kisah Athirah keutuhan dan keharmonisan keluarga masih terjaga, itu dikarenakan kepandaian Athirah dalam mengolah konflik dikeluarga, walaupun dia merasa sakit hati kepada suami akibat diduakan, akan tetapi rasa hormat tidak hilang dan sikap dia yang baik tetap ditunjukkan kepada suami dan keluarga lain. Rasa sakit yang Athirah alami dia alihkan pada kesibukan lain, yakni tekat Athirah untuk mendidik anaknya menjadi orang sukses dan mengisi waktunya dengan berbisnis.

Namun sebaik apapun Athirah mengontrol hati, ada kalanya tiba-tiba rasa marah itu muncul ketika dihadapkan pada sesuatu yang tidak mengenakkan hati. Hal itu terjadi ketika sang suami dia ajak untuk menghadiri pernikahan anak saudaranya akan tetapi Kalla sang suami mengatakan bahwa dia banyak urusan bisnis, setelah tiba hari hajatan pernikahan itu Athirah berangkat bersama Yusuf dan mengijinkan kepada tuan rumah bahwa suaminya tidak bisa hadir. Betapa terkejut Athirah dan Yusuf karena tanpa mereka duga, Kalla datang bersama istri muda, betapa malunya Athirah karena dia sudah memamitkan suami yang tidak akan datang kehajatan ternyata datang dengan perempuan lain.

Terkadang beban psikologi yang terlalu berat karena memiliki keluarga yang berpoligami mengakibatkan isteri dan anak-anaknya menjadi hilang kepercayaan 
diri ketika mereka bergaul dalam masyarakat sosial. Seperti ungkapan yang tejadi dalam novel Athirah:

“Dalam suatu pesta emma' bertemu bapak dan isteri kedua bapak. marahku bahkan terbendung lagi, entah hendak berteriak atau menangis. Apalagi emma, tiba-tiba dia ingin menangis. Yang paling perih dalam poligami adalah bila perasaan terdampingi terampas oleh orang lain. Ku gengam tangan emma lembut. Aku membuang muka ke sisi, takut mataku basah. Dan takut pula kudapati mata emma basah, kurasa kami sama-sama menagis didalam hati" (Endah, 2017:212-214).

Ungkapan diatas merupakan dampak poligami yang terjadi pada perempuan dan anak mereka bisa hilang kepercayaan diri. Beberapa studi yang dilakukan di berbagai negara di Timur Tengah dan Afrika menunjukkan bahwa anak-anak dari keluarga poligami mungkin menderita emosional, perilaku, dan masalah fisik, bersikap negatif, prestasi sekolah yang lebih rendah, dan lebih besar kesulitan dalam penyesuaian sosial daripada anak-anak dari perkawinan monogami. Walaupun ini tidak terjadi pada keluarga Athirah, bisa jadi teori ini berlaku kepada keluarga poligami lain, yang kurang mampu mengelolah resolusi konflik.

Di ahir cerita novel Athirahh diungkapkan bahwa banyak yang terluka akibat poligami baik dari pihak istri pertama, kedua dan anak-anak mereka, walaupun semaksimal mungkin Kalla ingin berbuat adil pada kenyataannya itu sulit dilakukan. Kencondongan hidup Kalla yang lebih banyak tinggal kepada istri muda mengakibatkan penyesalan dihati setelah Athirahh meninggal. Kalla pun mulai menurun kesehatannya sejak ditinggal Athirahh dan dia selalu mengenang kebaikan dan perngorbanan yang sudah dilakukan Athirahh. Dan Kalla menyusul Athirahh setelah seratus hari kematian Athirah (Endah, 2017:379-381).

Jika diasumsikan dalam keluarga yang berpoligami, seorang bapak yang berpoligami maka dia harus bertanggung jawab dan mengurus lebih dari satu keluarga, disinilah Islam menuntut laki-laki untuk bisa berlaku adil. Komitmen 
pernikahan dan keluarga harus dibangun dan diatur sedemikian rupa karena poligami tidak hanya satu keluarga akan tetapi dua keluarga atau lebih. Keterbatasan waktu bertemu dan bergaul secara continou dengan anak diakibatkan karena harus membagi waktu dengan keluarga yang lain, menyebabkan anak merasa kurang kasih sayang bahkan yang lebih kronis lagi bisa menimbulkan kebencian sang anak kepada bapaknya.

Untung saja sosok Jusuf dalam novel Athirahh lebih mampu mengelolah kejiwaannya disebabkan beberapa faktor yaitu; Pertama, emma tidak pernah bercerita tentang kesedihannya dihadapan anak-anak dan juga tidak pernah mendoktrin sang anak untuk membenci bapaknya. Kedua, agama yang kuat sudah ditanamkan kepada Jusuf dan adik-adiknya sejak dini. Ketiga, pendidikan yang cukup sehingga mereka mampu mengontrol kejiwaan mereka.

Dampak lain yang bisa saja terjadi jika keluarga poligami tidak bisa berlaku adil adalah tumbuh rasa ketidak percayaan diri pada istri maupun anak, krisis kepercayaan ini bisa timbul karena rasa malu akibat banyak digunjing oleh masyarakat, atau juga bisa terjadi karena kekerasan yang ada dalam keluarga poligami. Dan yang terahir dampak dari poligami adalah timbulnya traumatik bagi anak terhadap lawan jenis. Pada individu anak berbeda cara penanganan traumatik ini, ada yang bisa dilakukan dengan mudah dan ada pula yang masih membutuhkan proses lama untuk menyembuhkannya. Oleh karena itu bagi keluarga poligami harus semaksimal mungkin untuk menjaga keharmonisan antara keluarga satu dengan keluarga lain.

\section{SIMPULAN}

Novel Athirah merupakan refleksi kehidupan nyata $\mathrm{H}$. Yusuf Kalla yang bercerita tentang dinamika keluarga yang berpoligami. Sejatinya cerita tentang kepedihan dan kepiluan yang dirasakan Athirahh akibat dipoligami, dijadikan cambuk oleh Athirahh untuk menjadi wanita yang lebih kuat dan mandiri. Sementara itu, kalla sebagai kepala rumah tangga sekaligus pelaku poligami berupaya untuk 
mempertahankan keutuhan rumah tangganya dengan semaksimal mungkin dengan berbuat adil kepada istri- istri dan anak-anaknya.

Akan tetapi dikarenakan adanya ketimpangan komitmen dan relasi dalam pernikahan poligami kalla, maka keadilan diantara istri-istrinya sulit diterapkan. Karna secara nafkah bathin kalla lebih banyak menghabiskan waktunya kepada istri muda. Dan secara keseluruhan kalla merupakan ayah yang baik dan bijaksana, dia telah dengan sempurna memberikan nafkah dan mendidik anakanaknya dengan baik sehingga anak-anaknya menjadi orang-orang sukses.

\section{DAFTAR PUSTAKA}

Ainiyah, Qurrotul. 2017. Eksistensi Perempuan dalam Keluarga: Pandangan Muhammad Nawawi Bin Umar dan Fatima Mernisi. An- Nisa'. Vol.9, No.1, 53-71.

2018. Contribution of Nawawi bin 'Umar in Family Confict Management. Justicia Islamica. Vol. 15, No.2, 211-226.

Bourdieu, Piere. 1998. Practical Reason; On The Theory of Action. California University Press.

Calhoun, J.F. \& J.R. Acocella. 1995. Psikologi tentang penyesuain dalam Hubungan Kemanusiaan. Terjm. R.S. Satmoko. Semarang: IKIP Semarang Press.

Carr, D. 1999. Encyclopedia of the life Coerse and Human Development. Vol.I: Childhood and Adolescence. New York: The Gale Group Inc, pp.335-340. D. Previti, \& P. R. Amato. 2003. "Why Stay Married? Rewards, Barriers, and Marital Stability". Journal of Marriage and the Family. Vol. 65 No. 3, 561-573 Endah. Alberthiene. 2016. Athirahh. Jakarta: Noura Books. Lane, Edward William. 1968. An English-Arabic Lexicon . Beirut: Librairie du Liban. Johnson, M.P. dkk. 1999. "The Tripartite Nature of Marital Commitment, Personal, Moral, and Structural Reasons to Stay Married", Journal of Marriage and the Family, Vol. 61 No. 1, 160-177. 
M. Arifin.tt. Hubungan Timbal Balik Pendidikan Agama di Lingkungan Sekolah dan Keluarga. Jakarta: Bulan Bintang.

Mashudi, Masdar Farid. 1997. Perempuan dalam Wacana Keislaman. Jakarta:Obor.

2000. Perempuan dalam lembaran kitab kuning:Membincang Feminisme Diskursus Gender Perspektif Islam. Surabaya: Risalah Gust.

McAuliffe, Jane Dammen (ed.). 2006. Encyclopaedia of the Qur'ān . Leiden: Brill. Mernissi, Fatima. 1999. Women's Rebellion and Islamic Memory: Pemberontakan Wanita, alih bahasa, Rahmawati Astuti. Bandung: Mizan.

Mudzakir. As. 1987. Keluarga Muslim dan Berbagai Masalahnya. Bandung: Penerbit Pustaka.

Mulia, Siti Musdah. 2004. Islam Menggugat Poligami. Jakarta: Gramedia.

Murdock, G.P. 1965. Social Structure. New York: The McMillan Company.

Mufidah Ch. 2008. Psikologi Keluarga Islam Berwawasan Gender. Malang: UIN Malang Press.

Muzani, Suprapti Muzani. 2014. Gender Dalam Perspektif Syari'ah. Sawwa. Vol.10 No.1.

Nurhayati. Eti. 2012. Psikologi Perempuan: dalam Berbagai Perspektif. Yogyakarta: Pustaka Pelajar.

S. Lestari. 2012. Psikologi Keluarga: Penanaman Nilai dan Penanganan Konflik dalam Keluarga. Jakarta: Kencana.

Taylor, Shelley E. dkk. 1997. Social Psychology. New Jersey: Prentice Hall.

Watt, W. Montgomery. 1956. Muhammad at Medina . Oxford: The Clarendon Press. 